\title{
SYSTEMATIC REVISION OF CALMONIIDAE (TRILOBITA, PHACOPIDA) OF THE PONTA GROSSA FORMATION (DEVONIAN), PARANÁ BASIN, APUCARANA SUB-BASIN, BRAZIL
}

\author{
ANDRE MORI \& JULIANA DE MORAES LEME \\ Departamento de Geologia Sedimentar e Ambiental, Instituto de Geociências, USP, Rua do Lago, 562, \\ Cidade Universitária, 05508-900, São Paulo, Brazil. \\ andr_mori@hotmail.com,leme@usp.br
}

\begin{abstract}
Previous taphonomic studies about the calmoniid trilobites of the Ponta Grossa Formation, Apucarana subbasin, revealed that some species might correspond to artificial taxa, or taphotaxa, whose diagnostic characters are artifacts of the fossilization process. This article presents a systematic revision of the Calmoniidae, and a discussion about the influence of taphonomy in the preservation of the diagnostic characters of this group, which can be altered by the external factors that they are exposed to. The most current record comprised 17 species of calmoniids in the Ponta Grossa Formation; an inaccurate number because it included invalid species that were never duly published, as well as some taphotaxa. At least eight species of calmoniids can be considered as artificial: Calmonia? gonzagana Clarke, C. signifer var. micrischia Clarke, Metacryphaeus granulata Popp, M. sedori Popp, Tibagya parana Struve, Paracalmonia pessula Clarke, P. salamunii Popp et al., and $P$. mendesi Popp et al., and are herein synonymized with previously erected species. This revision highlights the importance of allying a taphonomic vision with the taxonomic studies in order to reach a more accurate depiction of the calmoniid diversity. Furthermore, the designation of new species should be based preferably on numerous, well-preserved specimens in order to avoid the erection of artificial taxa.
\end{abstract}

Key words: systematics, trilobite, Calmoniidae, Devonian, Ponta Grossa Formation, Paraná Basin.

RESUMO - Estudos tafonômicos anteriores sobre os trilobitas calmoniídeos da Formação Ponta Grossa, Sub-bacia Apucarana, revelaram que algumas espécies possam corresponder a táxons artificiais, ou tafotáxons, cujos caracteres diagnósticos são artefatos do processo de fossilização. Esse artigo apresenta uma revisão sistemática de Calmoniidae e uma discussão sobre a influência da tafonomia na preservação dos caracteres diagnósticos desse grupo, os quais podem ser alterados pelos fatores externos aos quais eles estiveram expostos. A mais recente contagem inclui 17 espécies de calmoniídeos na Formação Ponta Grossa; um número impreciso, pois incluiu espécies inválidas que nunca foram publicadas, bem como alguns tafotáxons. Pelo menos oito espécies podem ser consideradas como artificiais: Calmonia? gonzagana Clarke, C. signifer var. micrischia Clarke, Metacryphaeus granulata Popp, M. sedori Popp, Tibagya parana Struve, Paracalmonia pessula Clarke, P. salamunii Popp et al., e P. mendesi Popp et al. foram aqui sinonimizadas com espécies anteriormente descritas. Essa revisão sistemática destaca a importância de aliar a visão tafonômica aos estudos taxonômicos a fim de alcançar uma representação mais precisa da diversidade de calmoniídeos. Além disso, a designação de novas espécies deve ser preferivelmente baseada na presença de vários espécimes bem preservados, a fim de evitar designação de táxons artificiais.

Palavras-chave: sistemática, trilobita, Calmoniidae, Devoniano, Formação Ponta Grossa, Bacia do Paraná.

\section{INTRODUCTION}

The marine macroinvertebrate fauna of the Devonian in Paraná, Ponta Grossa Formation is one of the most diverse faunas of the Paleozoic in Brazil. Systematic reviews of the invertebrates have dealt with Linguliformea (Bosetti, 1989a,b; Bosetti \& Moro, 1989; Zabini, 2007, 2011; Zabini et al., 2012) and Rhynchonelliformea brachiopods (Quadros, 1987; Cerri, 2013), Bivalvia (Kotzian, 1995, 2003), Gastropoda (Kotzian \& Marchioro, 1997; Marchioro et al., 1998), Tentaculida (Ciguel, 1989; Azevedo-Soares, 1999), Cnidaria, and Conularida (Leme, 2002; Leme et al., 2004, 2008, 2010). In addition, the calmoniid trilobites are amongst the most common and conspicuous groups of the fossil record in the Ponta Grossa Formation, Paraná Basin, Apucarana Sub-basin. Species are particularly abundant in pelitic facies generated within or below the storm wave base level (Clarke, 1913; Popp, 1985; Carvalho \& Edgecombe, 1991; Popp et al., 1996; Carvalho et al., 1997; Soares et al., 2008a; Leme et al., 2010; Mori \& Leme, 2012; Mori, 2013).

The studies with calmoniids in the Ponta Grossa Formation began with the classic monograph of Clarke (1913), who described not only trilobites, but also several other groups of marine invertebrates. After this, many other authors have contributed to the knowledge of this family (Clarke, 1890, 1913; Kozlowski, 1913, 1923; Struve, 1958; Copper, 1977; 
Eldredge \& Ormiston, 1979; Cooper, 1982; Carvalho \& Edgecombe, 1991; Popp et al., 1996; Ghilardi \& Simões, 2007; Soares et al., 2008a; Leme et al., 2010; Mori \& Leme, 2012; Mori, 2013).

Popp (1985) reviewed the calmoniids of the Ponta Grossa Formation in her monograph and designated six new species, five of which are considered invalid because they were never duly published. A few years later, Popp et al. (1996) revised the genus Paracalmonia, and erected three new species, whose current standings are discussed in this paper. Ghilardi \& Simões (2007) presented a historical synthesis of the development of paleontological researches with trilobites in Brazil, and also compiled a general list of valid calmoniid species described in the Paraná Basin, which was later updated by Soares et al. (2008a), totaling 17 species. However, Soares et al. (2008b) stated that the calmoniid diversity in the Paraná Basin is potentially lower, because some of these species might be taphonomic species that were erected based on diagnostic characters, which were possibly altered via the fossilization process or by weathering (Holz \& Schultz, 1998; Simões et al., 2003, 2009; Soares et al., 2008b).

More recently, Leme et al. (2010), Mori \& Leme (2012) and Mori (2013) presented preliminary data from a systematic revision of Calmoniidae from the Ponta Grossa Formation. Such data revealed that it is possible to assert that at least five of the 17 described calmoniid species correspond to taphotaxa. However, these authors highlighted the fact that a more comprehensive study would be necessary to reach the best clarification of the taxonomic problems, as well as to accomplish a finely resolved systematic revision. Based on these observations, the current status of the calmoniid species can be questioned.

Hence, the main goal of the present contribution is to provide a systematic revision of the Calmoniidae from the Ponta Grossa Formation, Sub-basin Apucarana, involving a taphonomic analysis of the specimens studied.

\section{GEOLOGICAL SETTING}

The Ponta Grossa Formation is situated in the Paraná Basin, extending over more than one state of Brazil (Figure 1). The specimens analyzed in this work all come from the Apucarana Sub-basin, and they were collected in the Paraná State, specifically from the municipalities of Jaguariaíva and Ponta Grossa, and also from the municipality of Tibagi to a lesser extent (Figure 1). The Jaguariaíva county stratigraphic section is summarized in Figure 2. In this section, the Ponta Grossa Formation is up to $80 \mathrm{~m}$ thick and consists predominantly of shales and siltstones. Shallow marine, finegrained sandstones bearing wavy structures and hummocky cross-stratification occur at the base of the unit (Petri, 1948; Lange \& Petri, 1967; Melo, 1988), whereas the rest of the section is made up of fairly fossiliferous muddy shelf rocks, mainly light-grayish siltstones, strongly bioturbated, which are intercalated with massive, dark shales. These shales were deposited below storm wave base and represent the record of marine flooding surfaces (Bergamaschi, 1999). Stratigraphic
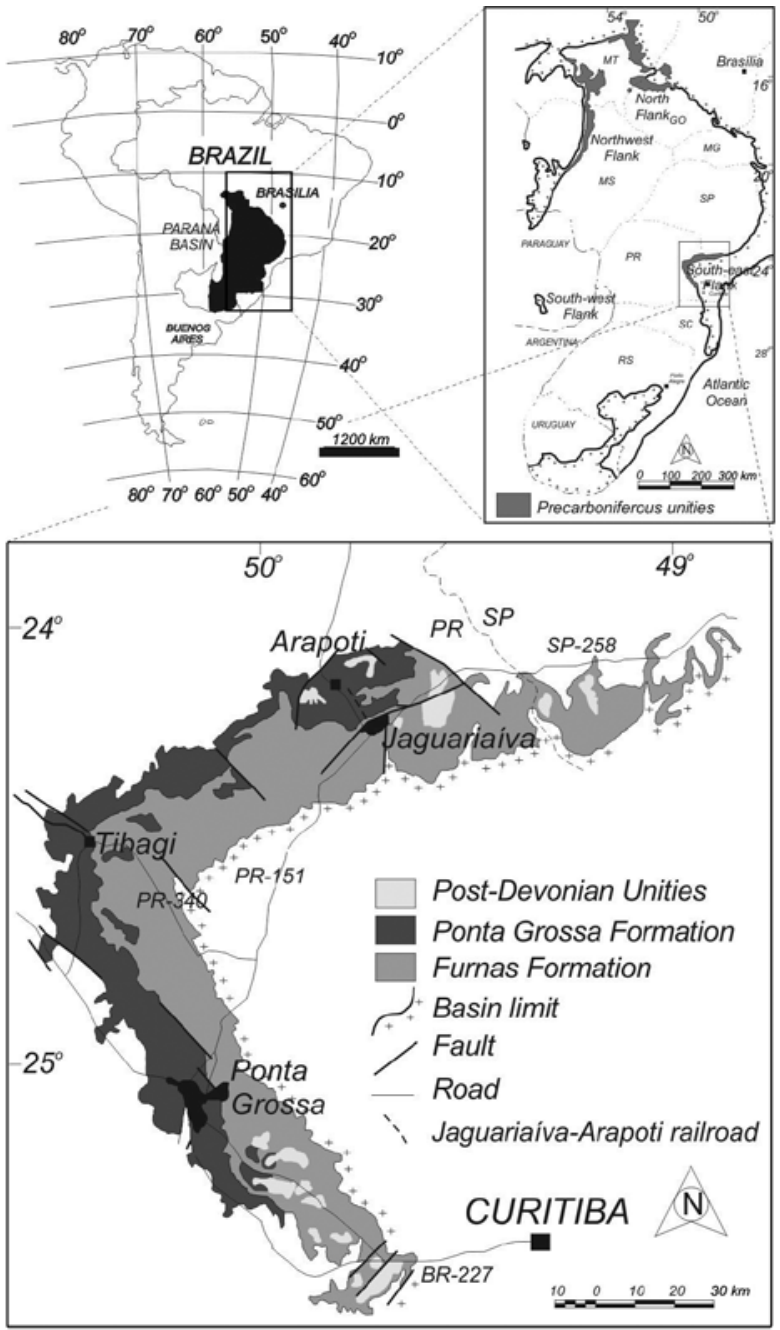

Figure 1. Map with locations of the studied geological sections, Ponta Grossa Formation, State of Paraná, Brazil.

intervals particularly suitable to Calmoniidae collecting are the

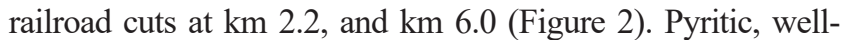
laminated, poorly fossiliferous dark shales enclose the Devonian sequence at the top of the Jaguariaiva section (Petri, 1948; Lange \& Petri, 1967; Melo, 1988; Bergamaschi, 1999; Bergamaschi \& Pereira, 2001) (Figure 2). According to Bergamaschi (1999), these rocks record the transgressive maximum in the area and were deposited under dysaerobic bottom conditions, as indicated by the scarcity of burrowing fauna.

\section{MATERIAL AND METHODS}

The analysis of material entailed collections from several institutes, including Departamento Nacional de Produção Mineral (DNPM), Universidade Estadual de Ponta Grossa (UEPG), Universidade Estadual de São Paulo (UNESP), Universidade Federal do Paraná (UFPR), Universidade Federal do Rio de Janeiro (UFRJ), Universidade de Guarulhos (UnG) and Universidade de São Paulo (USP). The correspondence between the acronyms used to number each fossil and the institute from which they derive is as follows: fossils identified with DGM are from DNPM; DZP from 


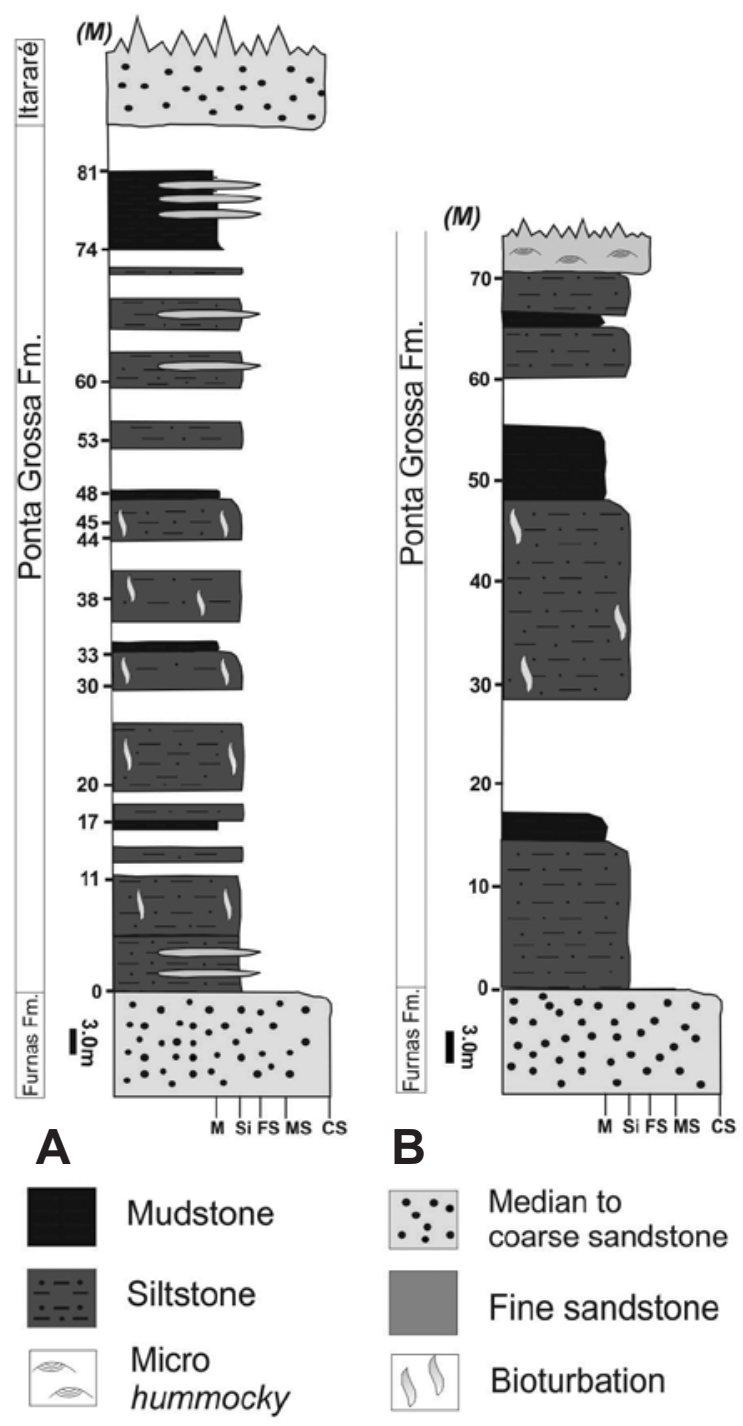

Figure 2. Columnar sections of the Ponta Grossa Formation. A, Columnar section at the Jaguariaíva-Arapoti railroad, Jaguariaíva County. B, Composed columnar section of the Ponta Grossa Formation. At the base, the rocks cropping-out along the PR-340 highway, Tibagi County. In the middle/upper portion of the section, the rocks of the Ponta Grossa Formation that are exposed along the road from Tibagi to Telêmaco Borba. All columnar sections modified from Ghilardi (2004), Bosetti (2004) and Soares et al. (2008b).

UNESP; CPUFPR and NR from UFPR; Tr from UFRJ; MN from Museu Nacional (UFRJ); UEPG from UEPG; TPg from UnG; and GP/1E and GP/1C from USP.

In total, 838 trilobite fossils were examined with a stereomicroscope and microscope. In some cases, molds made of a mixture of latex and silicon were produced to highlight important features. The photographs were taken using a Zeiss stereomicroscope, model SV6, digital camera, and the Axiovision software. Most of the specimens used for pictures were fumigated with magnesium oxide.

The systematic description follows the morphological terms applied by Clarke (1913), Eldredge \& Branisa (1980), Lieberman et al. (1991) and Lieberman (1993).

Terminology: L0, occipital lobe; L1-L3, glabellar lobes; S0, occipital furrow; L1-L3, glabellar furrows.

\section{SYSTEMATIC PALEONTOLOGY}

\author{
Family CALMONIIDAE Delo, 1935 \\ Subfamily CALMONIINAE Delo, 1935
}

Calmonia Clarke, 1913

Type species. Calmonia signifer Clarke, 1913; original designation. Devonian, Brazil.

\section{Calmonia signifer Clarke, 1913}

(Figures 3A-F)

1913 Calmonia signifer Clarke, p. 121, pl. 6, figs. 1,3,4,5,7-12. 1913 Calmonia ? gonzagana Clarke, p. 131, pl. 7, fig. 1 (n. syn.) 1913 Calmonia signifer var. micrischia Clarke, p. 124, pl. 6, figs. 13-16 (n. syn.)

1985 Calmonia paranaensis Popp, p. 103, pl. 2, figs. A-E (nom.nud.)

Diagnosis. Genal angle angular; glabella pentagonal and inflated; lateral glabellar furrows obscure, except for S1, S1 and $\mathrm{S} 3$ confluent with axial furrows; thorax bearing pleural spines; pygidium with 5 pairs of ribs, and 6 pairs of lateral spines; short terminal spine.

Material. DGM 13 (lectotype), DGM 17, DGM 19, DGM 22, DGM 30, DGM 1576, DGM 1577, DGM 3709, DZP18401, GP/1C423, GP/1E4790, NR 3106, NR3110, NR3133b, NR3181, NR3878, NR3956, NR6473, TPg1, TPg72. Type of sclerites: three complete exoskeletons, four cephala, five thoraxes with pygidia, eight pygidia.

Occurrence. Municipalities of Jaguariaíva, Ponta Grossa and Tibagi, Ponta Grossa Formation, (Pragian/Eifelian).

Description. Exoskeleton oval in outline; cephalon short (sag.) and subtriangular, bearing a short frontal median process; eyes small, distant from the posterior border, and positioned very close to the glabella, Large Eye Index around 0.35 , genal angles angular, with short genal spines; axial furrows slightly divergent forward and shallow, cephalic length measuring around $33 \%$ of total exoskeletal length. Glabella large, pentagonal in shape, usually inflated when compared with the cheeks, frontal lobe more inflated than lateral lobes, L0 moderately curved forward, especially in the middle, lateral glabellar lobes depressed and subequal in size, all in the same plane, L1 moderately curved; L2 and L3 slightly curved, L2 and L3 connected fused distally. S0 deep, curved forward medially; lateral glabellar furrows weakly developed, except for S1; S1 relatively deep, almost straight, reaching axial furrows; S2 shallow and straight, disconnected from axial furrows; S3 almost transverse, slightly bent in a curve, shallower than S1, confluent with axial furrows; glabella longer than wide (width across the frontal lobe about $85 \%$ of total glabellar length); glabellar width around $50 \%$ of cephalic width. Thoracic pleurae ending in spines, pleural spines directed slightly backwards; axis narrower and more elevated than pleurae, all the rings curved to the front, especially in the middle, axial furrows 
shallow and parallel; inter-ring furrows wavy and deeper than axial furrows; pleural furrows deep and straight, becoming more transverse towards the end portion of the thorax; thoracic length around $44 \%$ of total exoskeletal length. 11 thoracic segments.

Pygidium triangular in outline with anterior margin almost convex and lateral margins almost straight diagonally; axial furrows slightly divergent forward in the anterior portion, but becoming straighter posteriorly; inter-ring furrows straight and shallow, interpleural furrows shallow and transverse, becoming shorter towards the posterior margin. Axis not elevated above pleural fields; axis with eight or nine rings; pleural fields bearing five pairs of ribs; pygidial margin with six pairs of spines, all directed backwards; posterior margin ending in a small terminal spine, pygidium wider than long (length about $60 \%$ of width, not including terminal spine); pygidial length occupying around $23 \%$ of total exoskeletal length.

Remarks. Calmonia signifer is by far the most abundant trilobite of the Ponta Grossa Formation. Aside from the common occurrences, it is also relatively easy to identify, even if the fossils are not completely articulated, mostly because of the distinctive characters on the cephalon and pygidium, such as the characteristic set of spines (Figures 3A-C, E).

Clarke (1913) described and named one pygidium from Jaguariaíva as Calmonia? gonzagana, and compared it with C. signifer, pointing out that the former differs only by having axial tubercles and lacking marginal spines. However, the revision of this pygidium did not reveal any tubercles, save for one small bump that does not appear to be a taxonomic character, but instead a taphonomic one (Figure 3D).

The problem with using only spines to separate species is that it is necessary to consider that such structures are liable to being broken and therefore lost. In fact, it is very rare to find a pygidium with a full set of 12 pleural spines plus the entire terminal spine preserved. The pygidium assigned to C. ?gonzagana (Figure 3D) shows broken lateral and posterior margins, which can explain the absence of the marginal and terminal spines. Hence, $C$. ?gonzagana, is regarded herein as a synonym of $C$. signifer.

Clarke (1913) also erected Calmonia signifer var. micrischia (Figure 3F), noting that it represents a transition between Calmonia and Pennaia because of the presence of four pairs of marginal spines and pleural ribs (one less pair than Calmonia and one more pair than Pennaia). However, the analysis of the specimen designated as $C$. signifer var. micrischia revealed that the anterior margin of the pygidium could be incomplete, and the lateral margins are not very well preserved, which means that the number of visible spines could be misleading. In this paper, this variation of C. signifer is no longer considered as valid, for the characters used to diagnose it could easily be explained by incomplete or poor preservation.

\section{Kozlowskiaspis Branisa \& Vanek, 1973}

Type species. Kozlowskiaspis superna Branisa \& Vanek, 1973; original designation. Devonian, Brazil.
Kozlowskiaspis subseciva Clarke, 1913

(Figures 3G-J)

1913 Calmonia subseciva Clarke, p. 126, pl. 7, figs. 2-10.

Diagnosis. Cephalon subtriangular in outline; genal angles rounded, without spines; frontal glabellar lobe inflated; S3 sinuous; anterior and lateral cephalic border distinct; pygidium with five pairs of ribs; pygidial marginal and terminal spines absent.

Material. DGM 25 (holotype), DGM 26, DGM 27, DGM 28, DGM 29, CPUFPR-80, 87Tr. Types of sclerites: two complete exoskeletons, one cephalon, two thoraxes with pygidia, two pygidia.

Occurrence. Municipalities of Jaguariaíva, Ponta Grossa and Tibagi, Ponta Grossa Formation, (Pragian/Eifelian).

Description. Exoskeleton oval in outline; cephalon proportionately short (sag.) and subtriangular, without frontal median process; eyes small, distant from the posterior cephalic border, positioned very close to the glabella; Large Eye Index around 0.33; genal angles rounded, without genal spines; axial furrows shallow, slightly divergent forward; cephalic length measuring around $28 \%$ of total exoskeletal length. Glabella large, pentagonal in shape, frontal lobe wide (tr.), more inflated than lateral lobes; L0 moderately curved forward, especially in the middle; lateral glabellar lobes depressed and subequal in size, all in the same plane; L1 moderately curved, L2 and L3 slightly curved, L2 and L3 fused distally. S0 deep, curved forward medially; lateral glabellar furrows weakly developed, with except for S1, S1 relatively deep, almost straight, disconnected in the middle, reaching axial furrows; S2 shallow and straight, without contact with axial furrows; S3 almost transverse, sinuous, deeper than S2 but shallower than S1, confluent with the axial furrow; glabella longer than wide (width across the frontal lobe about $83 \%$ of total glabellar length); glabellar width around $50 \%$ of cephalic width. Thoracic pleurae without pleural spines; axis narrower and more elevated than pleurae; all the rings curved to the front, especially in the middle; axial furrows shallow moderately deep and parallel, inter-ring furrows wavy and deeper than axial furrows, pleural furrows deeper and straight, becoming more transverse towards the terminal portion of the thorax; thorax wider than long anteriorly (length around 70\% of width), but becoming longer than wide as it gets closer to the pygidium (width in the ultimate thoracic segment around $82 \%$ of length); thoracic length around $52 \%$ of total exoskeletal length. Eleven thoracic segments. Pygidium subtriangular in outline, anterior margin curved forward, lateral margins almost straight diagonally, axial furrows slightly divergent forward in the anterior portion, but becoming straighter towards the posterior margin; inter-ring furrows straight, distinct, axis in the same plane as the pleurae; axis with eight or nine rings; pleurae bearing five pairs of ribs, without marginal spines, posterior margin ends in acute extremity, terminal spine absent, pygidium wider than long (length about $57 \%$ of width, not including terminal spine); pygidial length measuring around $30 \%$ of total exoskeletal length. 
Remarks. Initially described as Calmonia subseciva Clarke, 1913, this species was later transferred to the genus Kozlowskiaspis by Edgecombe (1994), due mostly to the presence of a wide, diamond-shaped frontal glabellar lobe and a broad arched cephalic outline (Figure 3H). As mentioned above, Soares et al. (2008b) observed problems in the systematics of calmoniids, stating that Clarke (1913) differentiated Calmonia subseciva from Calmonia signifer only because of the absence of a terminal spine in the pygidium, and raising questions about whether this difference could be merely a taphonomic artifact. However, the revision of the specimens described as C. subseciva revealed that there are enough characters to exclude them from the genus Calmonia, including those already highlighted by Edgecombe, 1994 (i.e. genal angles rounded and wide diamond-shaped frontal glabellar lobe). Furthermore, the posterior border of the pygidium is entire (see Figures 3G, I-J) so there does not seem to be any indication of a terminal spine. Thus, this species remains valid.

\section{Pennaia Clarke, 1913}

Type species. Pennaia pauliana Clarke, 1913; original designation. Devonian, Brazil.

\section{Pennaia pauliana Clarke, 1913}

(Figures 4A-D)

1913 Pennaia pauliana Clarke, p. 129, pl. 5, figs. 18-25.

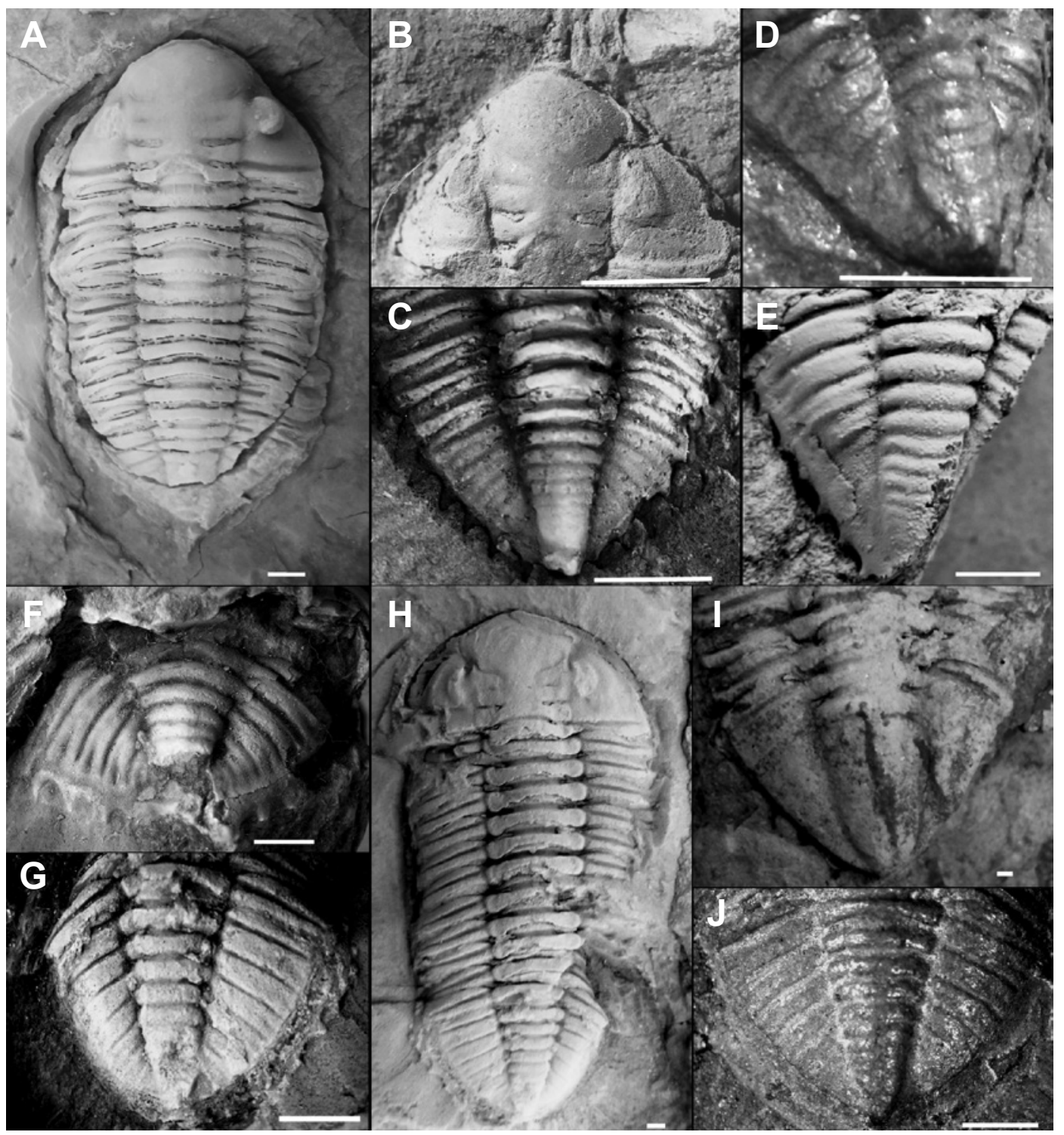

Figure 3. Internal molds of Calmonia signifer. A, DGM13; lectotype. B, NR3133B; cephalon with median frontal process. C, NR5906; pygidium and part of thorax, with pleural spines and terminal spine broken. D, DGM19; pygidium previously assigned to C. ? gonzagana, showing the supposed tuberculation on the pleural field. E, Tpg1; incomplete pygidium, with pleural spines. F, DGM22; pygidium previously assigned to C. signifer var. micrischia. Internal molds of Kozlowskiaspis subseciva. G, DGM25; pygidium of holotype. H, DGM25; entire exoskeleton of holotype. I, CPUFPR-80; thoracopygon. J, DGM28; pygidium. Scale bars $=5 \mathrm{~mm}$. 
Diagnosis. Medial frontal spine or genal spines absent, S1 and S3 confluent with axial furrows, pleural terminations rounded, terminal spine absent.

Material. DGM 71 (lectotype), DGM 72, DGM 74, DGM 75, DZP-17461, GP/1E4791, NR3104, NR3130, TPg211. Types of sclerites: two complete exoskeletons, one cephala, two thoraxes with pygidia, four pygidia.

Occurrence. Municipalities of Jaguariaíva, Ponta Grossa and Tibagi, Ponta Grossa Formation (Emsian).

Description. Exoskeleton oval in outline; cephalon proportionately short (sag.), triangular in outline; median frontal process and genal spines absent; eyes small, positioned very closely to the glabella, and very distant from the posterior cephalic border; Large Eye Index around 0.38; genal angles rounded; axial furrows divergent forward, especially around the front of the glabellar margin until L1, becoming progressively parallel; cephalic length measuring around $29 \%$ of the total exoskeletal length. Glabella large and pentagonal, frontal lobe more inflated than the lateral ones; L0 slightly convex and bent forwards in the middle, all lateral glabellar lobes depressed, with L3 being the longest and L1 the shortest, L1 moderately curved, L2 slightly curved, L3 triangular, L3 and L2 fused distally; S0 shallow and curved forward medially; lateral glabellar furrows with different sizes, with $\mathrm{S} 3$ being the longest, and S2 the shortest; S1 sinuous and shallow, reaching the axial furrows; S2 curved and shallow, disconnected from axial furrow; S3 transverse and the deepest, reaching the axial furrows; glabella longer than wide (width across the frontal lobe about $90 \%$ of length); glabellar width around $58 \%$ of cephalic width. Thorax ending in rounded extremities; axis very large, more inflated and wider than the pleurae; rings very thick, bending forward in the middle, axial furrows almost parallel; pleural furrows shallow; thoracic length around $55 \%$ of entire body length. Pygidium very short, semielliptical in outline; anterior margin strongly convex; axial furrows converging towards the posterior margin; inter-ring furrows shallow; interpleural furrows very shallow and transverse; axis a little more elevated than pleural fields; pleural fields bearing 3 lappets at the end of 3 ribs; all the lappets directed backwards; anterior margin convex; posterior margin between lappets is rounded, without a terminal spine; axis with 5 rings; pygidium much wider than long (length about $45 \%$ of width); pygidial length occupying around $16 \%$ of entire body length.

Remarks. Pennaia pauliana has been a well-established species since its conception by Clarke (1913) because of its unique pygidial characteristics. This taxon is very peculiar not only in showing a combination of three pleural ribs and three marginal spines, but also due to being the only calmoniid species in from the Ponta Grossa Formation to have a micropygidium (Figures 4B-D). Identification is usually straightforward when the pygidium is present. On the other hand, the cephalon is not so distinct, as it is basically similar to Calmonia but without cephalic spines (Figure 4A). Nonetheless, the revision showed that this species does not have any taxonomic problems.

Metacryphaeus Reed, 1907
1935 Hadrorachus Delo, p. 415.

1940 Hadroracos Delo, p. 9.

1942 Asteropyge Richter \& Richter, p. 174.

Type species. Phacops caffer Salter, 1856; original designation. Devonian, South Africa.

Metacryphaeus australis Clarke, 1913 (Figures 4E-I)

1913 Cryphaeus australis Clarke, 108-114, pl. 3, figs. 7, 9, 11-14; pl. 4, figs. 3-5.

1925 Dalmanites australis Reed, 145, pl. 11, fig. 9.

1935 Hadrorachus australis Delo, p. 415, figs. 34-35.

1938 Dalmanites australis Méndez-Alzola, p. 9, pl. 75-76.

1942 Asteropyge australis Richter \& Richter, p. 134.

1954 Asteropyge australis Lange, p. 48.

1985 Metacryphaeus sedori Popp, p. 87, pl. 5, figs. A-B

(nom. nud.)

1985 Metacryphaeus granulata Popp, p. 92, pl. 5, figs. C-D

(nom. nud.)

Diagnosis. Cephalon semicircular, without a median frontal process, genal angles subangular; S3 and S1 confluent with axial furrows; pygidial axis with eight to nine rings; pleural fields bearing five lappets with acute ends, all directed backwards; terminal spine absent.

Material. DGM 31 (lectotype), DGM 33, DGM 35, DGM 36, DGM 1581, DGM 1582, DGM 1991, GP/1C402, GP/1E7492, NR3099, NR3126, NR3130, NR3167, NR3202, NR5182, NR17821, TPg3b, TPg15, TPg29, 89Tr, UEPG17644. Types of sclerites: four complete exoskeletons, six cephala, two cephala with thorax, three thoraxes with pygidia, sis pygidia. Occurrence. Municipalities of Jaguariaíva, Ponta Grossa and Tibagi, Ponta Grossa Formation (Emsian-Givetian).

Description. Cephalon semicircular, highly vaulted, without a median frontal process; eyes small, very close to the glabella, and distant from the posterior border; Large Eye Index around 0.32; genal angles subangular; axial furrows deep and conspicuously divergent; cephalon surface smooth or with granulation; cephalic length corresponding to $26 \%$ of entire body length. Glabella large, pentagonal and inflated especially in the frontal lobe; frontal lobe oval, distinctly detached from rest of the glabella by S3; L0 sinuous, bending forward in the middle; lateral glabellar lobes with different sizes, with L3 the largest and L1 the smallest; L1 moderately curved; L2 slightly curved; L3 thick and triangular; L2 and L3 fused distally; S0 deep and convex; all lateral glabellar furrows visible and with distinct lengths, with $\mathrm{S} 3$ as the longest, and $\mathrm{S} 2$ as the shortest; S1 mostly straight and shallow, reaching the axial furrows; S2 also straight and shallow, disconnected from the axial furrows; S3 the deepest, transverse and confluent with the axial furrows; glabella a little longer than wide (width across the frontal lobe about $90 \%$ of length); glabellar width around $54 \%$ of cephalic width. Thorax ending in pleural lappets, all pointed outwards; axis more elevated and wider than the pleural fields; axial rings straight and thick; axial 


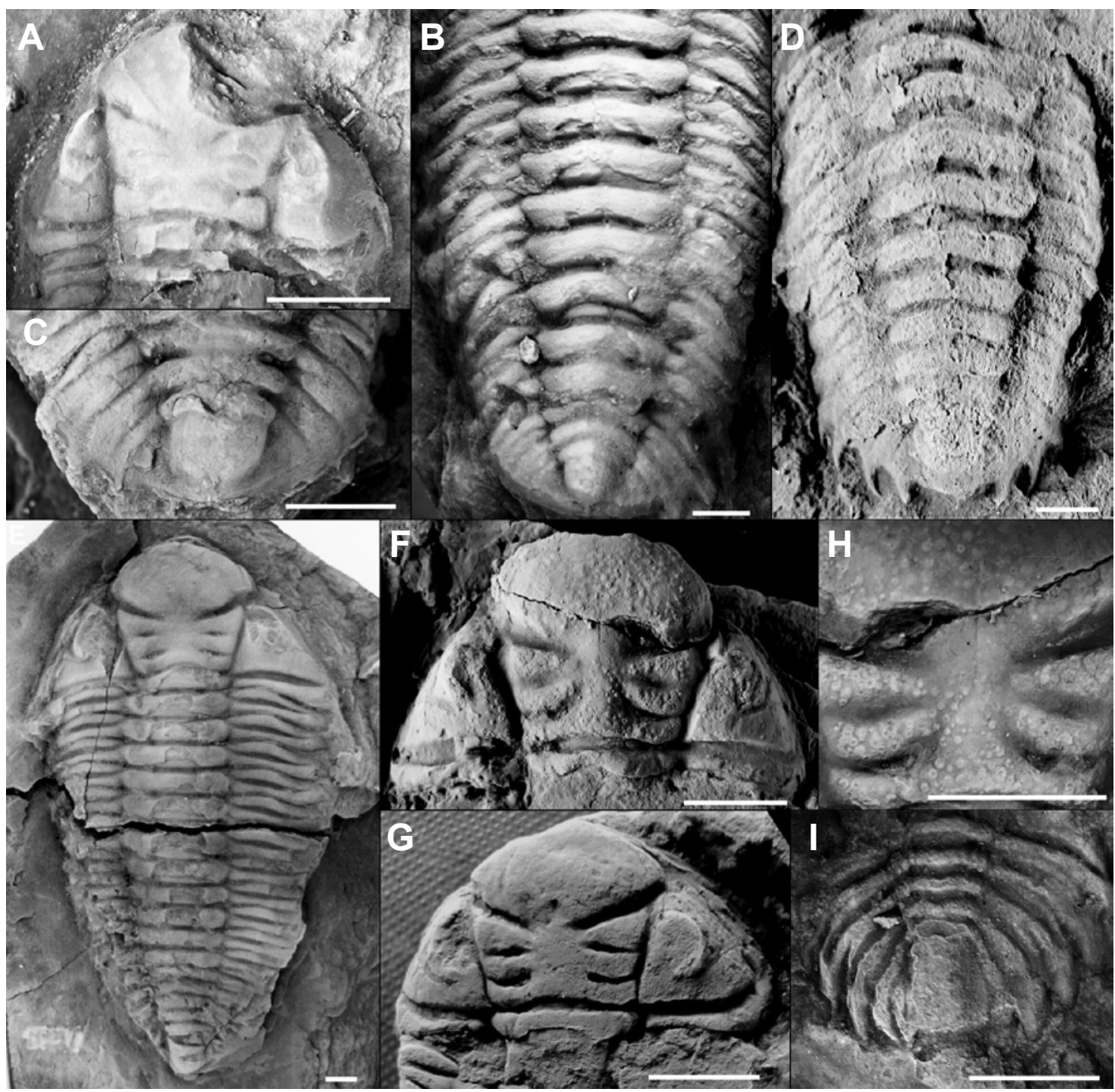

Figure 4. Internal molds of Pennaia pauliana. A, DGM71; broken cephalon. B, DGM74; pygidium of lectotype. C, DGM74, lectotype. D, GP/1E7491; latex mold of a thoracopygon, with the characteristic three pairs of spines. Internal molds of Metacryphaeus australis. E, DGM31, lectotype. F, NR3130; cephalon previously assigned to $M$. granulata, with the granulated surface. G, cephalon previously assigned to $M$. sedori. H, NR3130; glabellar granulation in detail. I, NR3167; pygidium, with the pleural lappets preserved. Metacryphaeus rotundatus. G, DGM69; pygidium of Tibagya parana. Scale bars $=5 \mathrm{~mm}$.

furrows straight, parallel; inter-ring furrows wavy and deeper than axial furrows; thoracic length around $53 \%$ of entire body length. Eleven thoracic segments. Pygidium semicircular and vaulted; anterior margin almost straight; lateral margins curved; inter-ring furrows moderately deep and convex; interpleural furrows shallow and transverse; axis in the same plane as pleural field, bearing eight or nine rings; pleural field with five ribs; lateral pygidium margin with five pleural lappets with acute ends, all directed backwards; axis ending before reaching posterior margin; terminal spine absent; pygidium wider than long (length about $57 \%$ of width); pygidial length around $21 \%$ of entire body length.

Remarks. Metacryphaeus australis is a very common trilobite species in the Ponta Grossa Formation. This species has undergone several name changes, mostly because the genus Metacryphaeus itself was the target of many discussions about its taxonomic standing (Reed, 1927; Rennie, 1930;
Delo, 1935; Richter \& Richter, 1942; Struve, 1959; Wolfart, 1968; Lieberman et al., 1991). Lieberman et al. (1991) and Lieberman (1993) made a comprehensive synthesis of the scope of Metacryphaeus. Popp (1985) erected Metacryphaeus granulata based on one cephalon showing distinct granulation, especially on the glabellar surface, which was the sole character considered to separate it from M. australis (Figures 4F, H). However, it was not an appropriate designation because there are specimens of $M$. australis with visible granulation on the exoskeletal surface, as already noticed by Lieberman et al. (1993). In the Ponta Grossa Formation, it is very common to find fossils with smooth surface, and the analysis of numerous exfoliated cephala of $M$. australis revealed that some specimens show very faint evidences or a smaller amount of these granules, demonstrating that the granulation can be lost due to exfoliation by taphonomic processes (e.g. weathering). Therefore, although this species 
remains as invalid (nomem nudum) because it was never duly published, it provides an example of another taxonomic character being influenced by taphonomy. Similarly, Popp (1985) proposed Metacryphaeus sedori (unpublished; nomen nudum) based on a very flattened and exfoliated cephalon, and stated that it differs from M. australis by having more rounded genal angles, a glabellar S2 furrow that is confluent with axial furrows, and a moderate cephalic arching (Figure $4 G)$. However, the revision of this material did not corroborate such differences. The genal angles and cephalic arching do not differ essentially from those of $M$. australis. In addition, S2 does not reach the axial furrows since L2 and L3 are fused. In any case, the confluence of the lateral glabellar furrows with the axial furrows is a character that should be assessed with caution because most of the trilobites from the Ponta Grossa Formation are partially exfoliated and/or compressed and their furrows are often filled or erased.

\section{Metacryphaeus parana Kozlowski, 1923}

(Figures 5A-C)

1892 Cryphaeus giganteus Ulrich, pl.1, fig. 7.

1913 Homalonotus parana Clarke, p. 97, pl. 3, figs. 5-6 (n. syn.)

1923 Cryphaeus australis var. rotundatus Kozlowski, pl. 3, figs. 1 and 11.

1958 Tibagya parana Struve, p. 301-302 (n. syn.)

1965 Metacryphaeus giganteus Branisa, pl.13, figs. 8, 11 and 12.

2010 Pennaia pauliana Bosetti et al., p. 58, fig. 6e.

Diagnosis. Frontal glabellar lobe rounded anteriorly; genal spine long and slender; pygidial axis bearing eight rings; pygidial pleurae with five ribs, all ending in large, posteriorly curved lappets having rounded terminations; posterior margin of pygidium rounded, forming a terminal lappet that overlaps the last axial ring; terminal spine absent.

Material. DGM 69, DZP-18570a, DZP-18626, NR3108, NR3201. Types of sclerites: one cephalon, one thorax with pygidium, three pygidia.

Occurrence. Municipality of Jaguariaíva and Ponta Grossa, Ponta Grossa Formation (Pragian-Givetian). The specimens were collected in $48 \mathrm{~m}$ at the base of Jaguariaíva-Arapoti railroad section, Jaguariaíva County, and at $48 \mathrm{~m}$ and $8 \mathrm{~m}$ at the base of composed columnar section of the Ponta Grossa Formation, Tibagi County (Figure 2).

Description. Cephalon semicircular, heavily arched, without median frontal process; eyes small, very close to the glabella, and distant from the posterior border; Large Eye Index around 0.32 ; genal angles acute, ending in genal spines; axial furrows deep, highly divergent, almost straight diagonally. Glabella large, pentagonal and inflated especially around the frontal lobe area; frontal lobe oval, distinctly detached from the rest of the glabella by S3; L0 sinuous, pointing forward in the middle; lateral glabellar lobes with different sizes, with $\mathrm{L} 3$ being the largest, and L1 the smallest L1 moderately curved; L2 slightly curved; L3 thick and triangular; L2 and L3 fused distally; S0 deep and convex; all three lateral glabellar furrows visible; $\mathrm{S} 3$ the longest, and S2 and S1 subequal in length; S1 almost straight, slightly concave and shallow, confluent with axial furrows; S2 straight and shallow, disconnected from axial furrows; S3 the deepest and thickest, transverse and confluent with axial furrows; glabella a little longer than wide (width across the frontal lobe about $85 \%$ of the length); glabellar width around $48 \%$ of cephalic width. Pygidium semicircular and vaulted; anterior margin slightly curved forward; axial

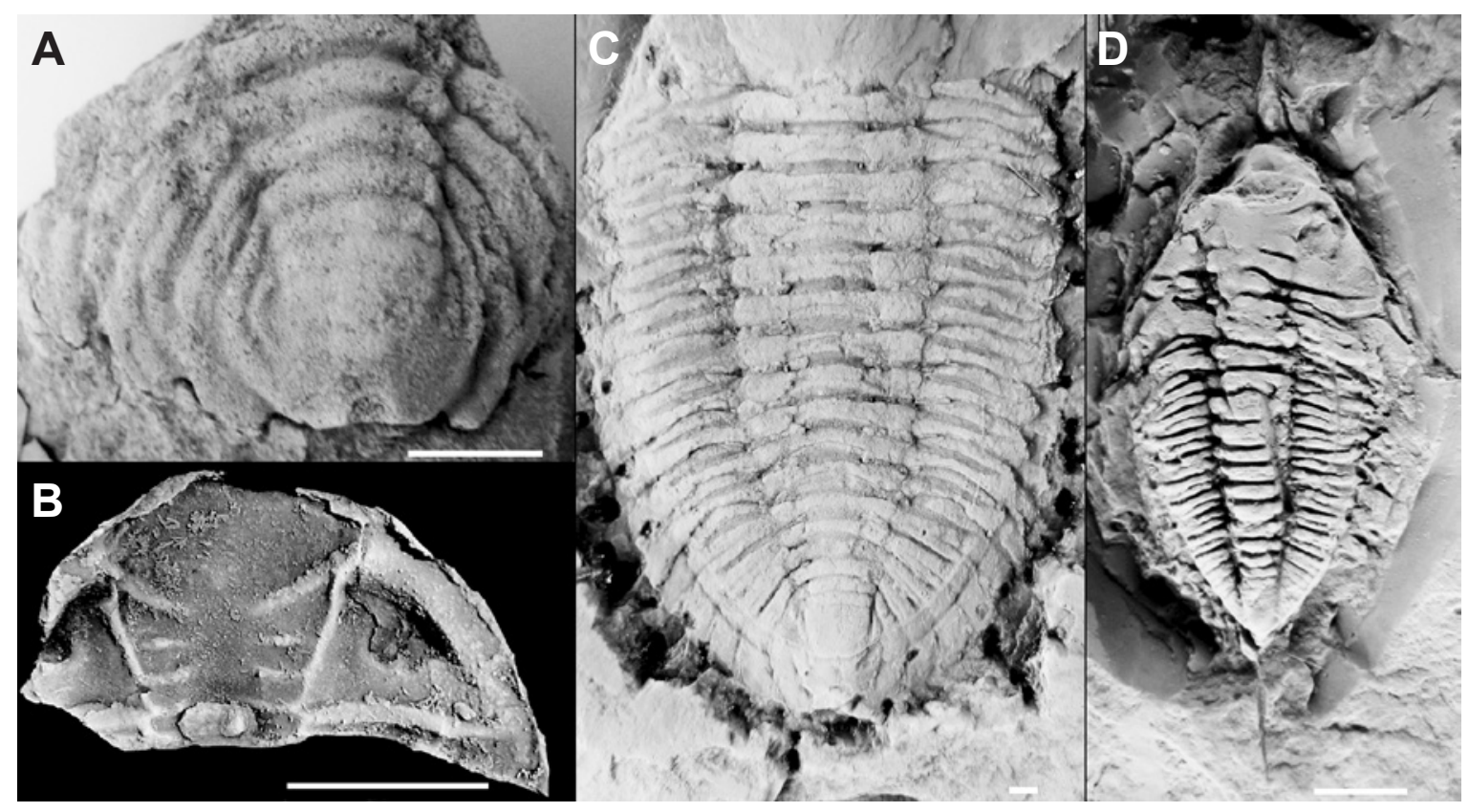

Figure 5. Metacryphaeus parana. A, DGM69; internal mold of pygidium previously assigned to Tibagya parana. B, DZP-18626; external mold of cephalon; photo taken by Soares et al., 2008a. C, NR3108; internal mold of thoracopygon. Paracalmonia cuspidata. D, NR2265A; internal mold of exoskeleton. Scale bars $=5 \mathrm{~mm}$. 
furrows divergent; inter-ring furrows curved; interpleural furrows shallow and transverse; axis more elevated than pleural field, bearing eight rings; pleural field with five ribs, all of which ending in large lappets, with rounded terminations; posterior margin of pygidium rounded, with a terminal lappet that overlaps the last axial ring; terminal spine absent.

Remarks. This species was initially considered a variation of Cryphaeus australis by Kozlowski (1923). Later on, Lieberman (1993) elevated M. rotundatus to species level, stating that $M$. rotundatus is the sister-group of Metacryphaeus giganteus, and not of M. australis, because of the long genal spine that they share. Struve (1958) erected the monospecific genus Tibagya based only on a pygidium that had been assigned to Homalonotus parana by Clarke (1913) (see also Thomas, 1977) (Figure 5A). This pygidium looked very similar to Metacryphaeus australis, but Struve (1958) erected the new genus based mostly on two characteristics: the pygidial pleural lappets, which are thicker than those of M. australis, and the presence of four pairs of pleural ribs and lappets, which differ from the typical five pairs of Metacryphaeus. However, a close study of the type specimen of Tibagya parana (DGM69) revealed that it is actually incomplete; because its anterior part is broken, certainty about how many pleural ribs and lappets really existed is not possible to achieve (Figure 5A). The presence of pleural lappets and a pygidial-rounded termination indicates that this pygidium belongs to Metacryphaeus and is conspecific with M. rotundatus. Thus, M. parana is regarded here as a senior synonym of $M$. rotundatus. $M$. parana was first described in the Devonian of the Paraná Basin by Soares et al. (2008a), utilizing characters such as the pigaxis extending in a termination that reaches the pleural lappets, rounded pleural lappets, long genal spine, and cephalic margin extended anteriorly (Figures 5B-C). Bosetti et al. (2010) interpreted one thorax and one pygidium as belonging to Pennaia pauliana. However, the analysis of the image (Bosetti et al., 2010, fig. 6e) revealed that the specimen actually corresponds to $M$. parana, because of the pygidium, which bears five pairs of pleural ribs and lappets, as well as the characteristic terminal lappet of this species, and none of these characters are found in Pennaia pauliana. This new assignment adds another specimen to $M$. parana, which is relatively rare in the Ponta Grossa Formation. Additionally, the occurrence of Metacryphaeus in the Ponta Grossa Formation was interpreted as Emsian - Givetian (Melo, 1988). The presence of M. parana in the basal portion of the Ponta Grossa Formation (Soares et al., 2008a) extends the distribution of the Metacryphaeus to Praguian- Givetian.

Paracalmonia Struve, 1958

1913 Proboloides Clarke, p. 135-139, Pl. 7, figs. 11-19.

Type species. Proboloides cuspidatus Clarke, 1913; original designation. Ponta Grossa Formation.

Paracalmonia cuspidata Clarke, 1913

(Figures 5D, 6A-F)
1913 Proboloides cuspidatus Clarke, p. 135-137, pl. 7, figs. 13-19.

1913 Proboloides pessulus Clarke, p. 138, pl. 7, figs. 11-12

(n. syn.)

1996 Paracalmonia paranaensis Popp et al., p. 23, fig. 4A-D

(n. syn.)

1996 Paracalmonia mendesi Popp et al., p. 29, fig. 5D-F (n. syn.)

Diagnosis. Cephalon triangular with long median frontal spine, usually longer than cephalon, separated from glabella by facial sutures surrounding frontal lobe closely; S1 and S3 confluent with axial furrows; fixigenal and prolibrigenal spines short; thorax with pleurae ending in spines; pygidium triangular with five pairs of pleural spines directed outwards; long terminal spine present, considerably longer than the rest of the pygidium.

Material. DGM 77, DGM 78 (lectotype), DGM 79, DGM 83, DGM 84, DGM 85, DGM 1580, DGM 3708, DZP18419, GP/1C404, CPUFPR31256, NR2265A, NR3131, NR3160, NR3161, NR3195, 5Tr, 34Tr. Types of sclerites: four complete exoskeletons, five cephala, two thoraxes with pygidia, seven pygidia.

Occurrence. Municipalities of Jaguariaíva, Ponta Grossa and Tibagi, Ponta Grossa Formation (Emsian).

Description. Cephalon triangular; frontal margin bearing a very large frontal spine, usually longer than the cephalon; eyes small, very close to the glabella, distant from the posterior border of the cephalon; Large Eye Index around 0.34; genal angles angular, bearing two small fragile spines in each side of the cheeks: one fixigenal and one prolibrigenal, both pointing outwards; axial furrows slightly divergent; cephalic length measuring around $31 \%$ of entire body length. Glabella pentagonal, not inflated; frontal glabellar lobe medium-sized and not inflated; $\mathrm{L} 0$ a little thick and almost straight, bending forward in the middle; lateral glabellar lobes subequal; L1 moderately curved; L2 and L3 slightly curved; L2 and L3 fused distally; S0 shallow and curved medially; all lateral glabelar furrows fairly visible and in different sizes, with S3 being the longest, and $\mathrm{S} 2$ the shortest; $\mathrm{S} 1$ the deepest and straight, confluent with axial furrows; S2 straight, shallow and obscure, disconnected from axial furrows; S3 transverse, shallow and obscure, reaching the axial furrows; glabella longer than wide (width across the frontal lobe about $77 \%$ of length); glabellar width around $59 \%$ of cephalic width.

Thorax ending in very acute spines directed outwards; axis narrower and more inflated than the pleurae; thoracic rings curved to the front in the middle; axial furrows shallow, almost parallel; pleural furrows shallow and wavy; thoracic length corresponding around $45 \%$ of entire body length. Eleven thoracic segments. Pygidium triangular; anterior margin straight; axial furrows convergent; lateral margins transverse; inter-ring furrows deep and straight; interpleural furrows shallow and transverse; axis not inflated, bearing seven or eight rings; pleural field bearing five ribs, with five pleural spines in each side of the pygidium, all pointing outwards; terminal spine present and longer than the pigydium; pygidium 
wider than long (length about $72 \%$ of width); pygidial length occupying $24 \%$ of entire body length.

Remarks. Clarke (1913) originally described this species as Proboloides cuspidatus based on the presence of a large frontal spine and prolibrigenal spines on each side of the cephalon. The name Proboloides was maintained until Struve (1958) substituted it for Paracalmonia, because the former is a homonym of Proboloides Della Valle, 1893 (Crustacea) and Proboloides Morley, 1903 (Hymenoptera). Clarke (1913) also erected Proboloides pessulus, renamed to Paracalmonia pessula, and based only on one specimen that had a median frontal process of different size. Unlike the frontal spine found in P. cuspidata, the frontal spine of Paracalmonia pessula has about the same length as the glabella, instead of being longer than it is (Figure 6D). In addition, the pygidium of $P$. pessula seems to be a little rounder than that of P. cuspidata, and apparently lacks marginal spines (Figure 6F). However, the pygidial margin of $P$. pessula is not well-preserved (Figure 6F) and it is more than likely that the absence of spines is a taphonomic character. In fact, the only character that would separate both species would be the size of the frontal spine. In the Ponta Grossa Formation, it is very hard to find specimens with complete spines, especially when they are as long as in Paracalmonia. The analysis of the specimens of Paracalmonia show that there is no rule to the size of the frontal spine in the specimens that were classified as $P$. cuspidata. In some cephala, the size of the spine is just a little longer than the cephalon, while other cephala
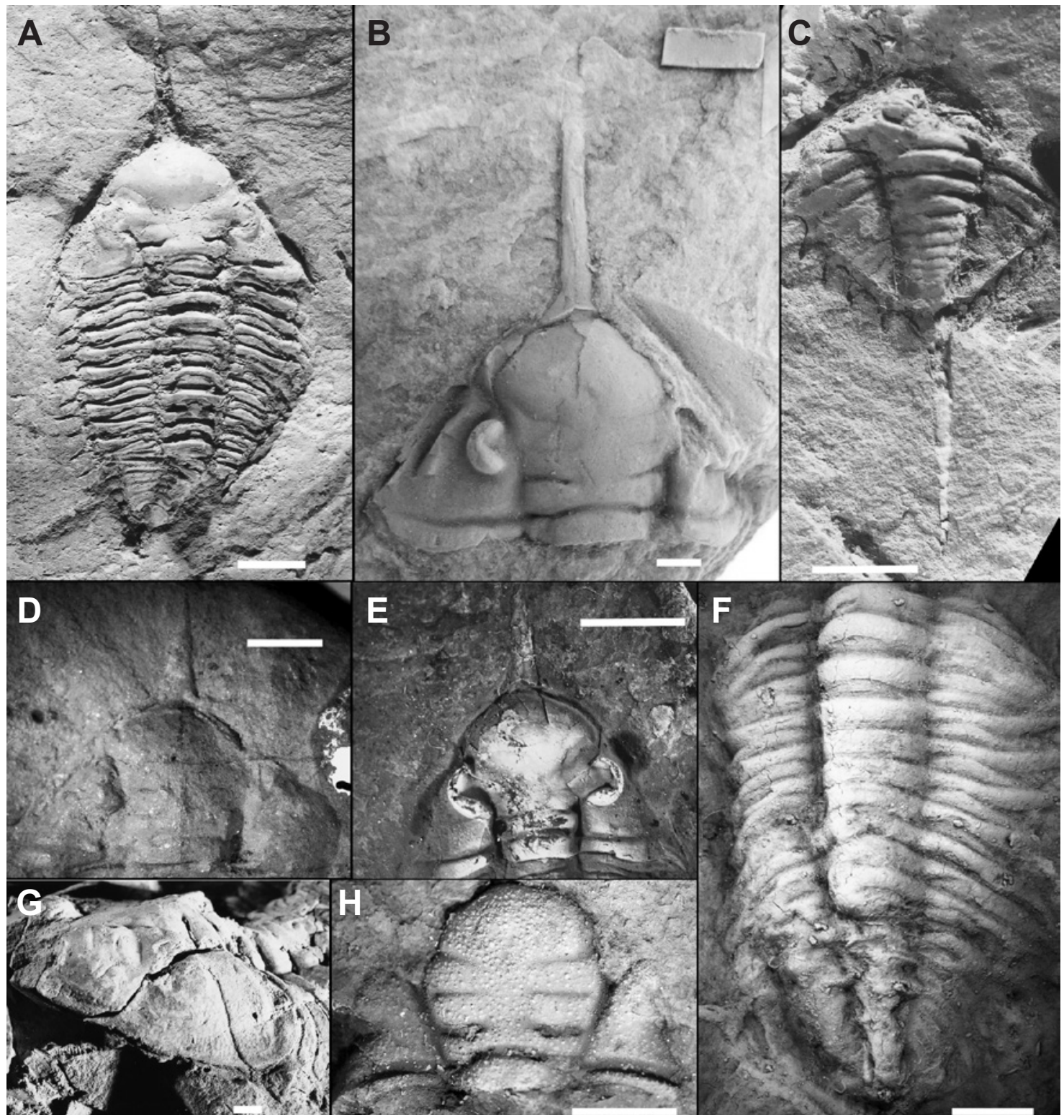

Figure 6. Internal molds of Paracalmonia cuspidata. A, CPUFPR-31256; exoskeleton previously assigned to $P$. paranaensis; photo taken by Popp et al., 1996. B, DGM78; lectotype, displaying the very large frontal spine. C, NR3195; pygidium, with pleural and terminal spines preserved. D, DGM85; poorly preserved cephalon previously assigned to $P$. pessula. E, GP/1C404; latex mold of a cephalon, with smaller frontal spine. F, DGM85; poorly preserved thoracopygon previously assigned to $P$. pessula. G, NR3161, detail of the poorly preserved glabella of $P$. salamunii. Photo taken by Popp et al., 1996. Paranacaste pontagrossensis. H, GP/1E7488; internal mold of glabella, showing distinct granulation. Scale bars $=5 \mathrm{~mm}$. 
show frontal spines measuring double the cephalic length (Figures 5D, 6A-B, E). Thus, P. cuspidata and P. pessula are regarded herein as synonyms, and the size of the frontal spine is considered to be a variable character. Popp et al. (1996) revised the genus Paracalmonia and erected three new species based mostly on glabellar characters. However, Soares et al. (2008b) questioned the validity of one of them, Paracalmonia paranaensis. Although Popp et al. (1996) distinguished $P$. paranaensis from $P$. cuspidata by having more inflated frontal and L3 glabellar lobes, Soares et al. (2008b) noticed that the glabellar lobes of the type material of $P$. paranaensis are compressed (Figure 6A), suggesting that $P$. paranaensis and $P$. cuspidata are synonyms. Similarly, Paracalmonia mendesi by Popp et al. (1996) was erected on the basis of an inflated frontal glabellar lobe, which was compared with that of P. paranaensis (Popp et al., 1996). Following Soares et al. (2008b), it is likely that the specimens of $P$. mendesi also represent well-preserved specimens of $P$. cuspidata. Carvalho \& Edgecombe (1991) had regarded the holotype of $P$. mendesi as conspecific with $P$. cuspidata; a reassignment that is endorsed herein. The third species erected by Popp et al. (1996), Paracalmonia salamunii, seems to differ from $P$. cuspidata also by differences in the glabella, including a sinuous S3 and shallow axial furrows at level of L2 and L3 (Popp et al., 1996). However, it is important to note that the holotype of $P$. salamunii is not well preserved, especially the glabella, which is compressed, fractured and exfoliated (Figure 6G). The glabellar lateral furrows and lobes are obscure and barely visible. Therefore, we cannot rule out the possibility that $P$. salamunii and $P$. cuspidata are synonyms.

\section{Paranacaste Popp, 1989}

Type species. Paranacaste pontagrossensis Popp, 1989; original designation. Ponta Grossa.

\section{Paranacaste pontagrossensis Popp, 1989}

(Figure 6H)

Diagnosis. Cephalic margin rounded medially; very large and inflated frontal glabellar lobe; granulation present on cephalon surface; genae bluntly angular; pygidium small and semicircular.

Material. GP/1E7488, DG-126Tr (holotype), DG - 127Tr. Types of sclerites: one cephalon, one cephalon with thorax, one thorax with pygidium.

Occurrence. Municipality of Jaguariaíva, Ponta Grossa Formation (Emsian).

Description. Glabella rounded and wide; glabellar surface with conspicuous granulation; frontal lobe highly inflated; L0 curved, bending slightly backwards in the middle; all lateral glabellar lobes distinct, with L3 being the largest, and L1 the smallest; L1 moderately curved; L2 and L3 inflated, slightly curved; S0 deep and convex; all lateral furrows visible, with $\mathrm{S} 3$ being the longest, and $\mathrm{S} 2$ and $\mathrm{S} 1$ being subequal in length; S1 deep and straight; S2 straight and shallow; S3 transverse and shallow; glabellar length and width subequal.
Remarks. Paranacaste was described as a monotypic genus by Popp (1989). Carvalho \& Edgecombe (1991) considered this species to be congeneric with Bainella, therefore transferring it to Bainella pontagrossensis. However, Carvalho \& Edgecombe (2006) found two specimens that matched the original description of Paranacaste pontagrossensis done by Popp (1989), and thus proposed the conservation of this taxon, based on the two new specimens. However, they proposed that the species specimen previously assigned by Carvalho \& Edgecombe (1991) as Bainella pontagrossensis should be kept in the genus Bainella, and so it was then renamed as Bainella paranaense by Carvalho \& Edgecomb (2006). A fragmentary cephalon from the municipality of Jaguariaíva is described herein (Figure 6H). The specimen shows the diagnostic characters of Paranacaste pontagrossensis Popp, 1989 such as a large, inflated and subcircular glabella, as well as a sculpture of raised granules. Paranacaste is reported from Jaguariaíva for the first time.

\section{DISCUSSION}

Lucas (2001) introduced the term "taphotaxon", referring to taxa that were erected based on taphonomic characters (i.e. characters that resulted from taphonomic processes, be it biostratinomic or diagenetic). Such term is deeply relevant to the scope of the systematic paleontology, considering that identifying characters altered during the fossilization process has been of one of the major concerns of paleontologists. In fact, there have been many studies in the Ponta Grossa Formation that analyzed groups under taphonomic vision, frequently leading to the invalidation of previously described species (Simões et al., 2003; Rodrigues et al., 2003; Leme et al., 2004; Ghilardi, 2004; Soares et al., 2008b; Simões et al., 2009; Leme et al., 2010; Mori \& Leme, 2012, Mori, 2013).

Ghilardi (2004) studied the trilobites of the Ponta Grossa Formation with this taphonomic approach, focusing on the taphonomic alterations that may have caused a poor interpretation of systematics. The author observed several preservation issues in different positions of the stratigraphic sequence, concluding that the taphonomy of these groups were complex and should be considered in any study about them.

Soares et al. (2008a) showed that so far 17 calmoniid species were reported from the Ponta Grossa Formation. However, several of these species might correspond to taphotaxa, with artificial characters that resulted from external factors. This is particularly evident for specimens that were preserved in different lithotypes or taphofacies, and therefore were subjected to distinct fossilization processes. For instance, the degree of compression of the different rocks and the exfoliation of the fossils are the main factors that obliterate and affect diagnostic characters of calmoniids (Soares, 2007; Soares et al., 2008b; Simões et al., 2009).

Soares et al. (2008b) had previously presented some morphological characters that might be altered taphonomically, for example: the shape and inflation of glabellar lobes, the depth of the axial and glabellar furrows and the presence or absence of external ornamentation (e.g. spines/lappets). 
In addition, here were observed that the shape and size of the axial and glabellar furrows, the confluence of the lateral glabellar furrows with the axial furrows, the size of the spines and the presence or absence of granulation or tuberculation throughout the exoskeleton are morphological characters that were modified by taphonomical process.

Calmoniidae is a family with great taxonomic similarity amongst the genera and species, which incurs the fact that the diagnostic characters are in many cases represented by small details. This causes several problems, since such details are malleable against the external factors to which the fossils and organisms are exposed. The results presented revealed that the diversity of calmoniids was overestimated beyond what Soares et al. (2008b) had already pointed out, with several other taphotaxa erected (see Table 1, for valid taxonomic species).

\section{CONCLUSIONS}

Based on the results presented in this paper, the following conclusions are obtained: (i) Paracalmonia cuspidata and $P$. paranaensis are considered as synonyms, as already suspected by Soares et al. (2008a); (ii) Calmonia ? gonzagana, as well as $C$. signifer var. micrischia, are considered as synonyms of $C$. signifer, which makes this genus monospecific in the Ponta Grossa Formation; (iii) Tibagya parana is synonymized with Metacryphaeus parana, now considered a senior synonym of $M$. rotundatus; (iv) Paracalmonia pessula and $P$. mendesi are considered as synonyms of P. cuspidata; (v) $P$. salamunii is considered as a nomen nudum, as the holotype was poorly preserved; (vi) a new occurrence of Paranacaste pontagrossensis is documented; (vii) now it is possible to provide an updated list of the valid calmoniid species of the Ponta Grossa Formation, which stands with eight species: Bainella paranaense Carvalho \& Edgecombe, 1991; Calmonia signifer Clarke, 1913; Kozlowskiaspis subseciva Clarke, 1913; Paracalmonia cuspidata Clarke, 1913; Paranacaste pontagrossensis Popp, 1989; Pennaia pauliana Clarke, 1913; Metacryphaeus australis Clarke, 1913; Metacryphaeus parana Kozlowski, 1923; (viii) the faunal diversity of calmoniid trilobites in the Ponta Grossa Formation is lower than what was previously thought; (ix) all these systematic results highlight the importance of adding a taphonomic view to the taxonomic study, in order to identify potential taphonomic characters that

Table 1. List of taxonomic valid species of Calmoniidae in the Ponta Grossa Formation, Paraná Basin, Apucarana Sub-basin, Brazil.

\begin{tabular}{cc}
\hline Species & Author \\
\hline Bainella paranaense & Carvalho \& Edgecombe, 1991 \\
Calmonia signifer & Clarke, 1913 \\
Kozlowskiaspis subseciva & (Clarke, 1913) \\
Paracalmonia cuspidata & (Clarke, 1913) \\
Paranacaste pontagrossensis & Popp, 1989 \\
Pennaia pauliana & Clarke, 1913 \\
Metacryphaeus australis & (Clarke, 1913) \\
Metacryphaeus parana & (Kozlowski, 1923)
\end{tabular}

might be used to create artificial taxa. They also stress the idea that the designation of new species must be based preferably on numerous and well-preserved specimens, as to allow the identification of taphonomic variations and their respective taxonomic consequences.

\section{ACKNOWLEDGEMENTS}

The authors of this article would like to express our gratitude towards the institutions and their respective professionals: R.R. Machado (DNPM), É.P. Bosetti (UEPG), M.G. Simões (UNESP), R.T. Bolzon and C.S. Vega (UFPR), I.S. Carvalho (UFRJ), A.C.S. Fernandes and V.M.M. Fonseca (Museu Nacional/UFRJ) and M.J. Garcia (USP). We would also like to thank J.C. Coimbra (UFRGS) for providing us with the original pictures taken by Popp et al. (1996), and M.G.P. Carvalho (American Museum of Natural History) for the assistance with our doubts concerning morphological terminology and trilobite research. Special thanks for both the reviewers, C. Crônier and F. Tortello that have greatly improved the manuscript.

\section{REFERENCES}

Azevedo-Soares, H.L.C. 1999. Classe Tentaculita na da Formação Ponta Grossa: uma proposta de sistematização. Faculdade de Geologia, Universidade Estadual do Rio de Janeiro, M.Sc. thesis, $132 \mathrm{p}$.

Bergamaschi, S. 1999. Análise estratigráfica do Siluro-Devoniano (Formação Furnas e Ponta Grossa) da sub-bacia de Apucarana, Bacia do Paraná, Brasil. Instituto de Geociências Universidade de São Paulo, Ph.D. thesis, 167 p.

Bergamaschi, S. \& Pereira, E. 2001. Caracterização de Seqüências Deposicionais de 3 a ordem para o Siluro-Devoniano da SubBacia Apucarana, Bacia do Paraná, Brasil. In: J.H.G. Melo \& G.J.S. Terra (eds.) Correlações de Seqüências Paleozóicas SulAmericanas, Rio de Janeiro, CENPES, p. 63-72 (Série Ciência Técnica Petróleo, Seção Exploração de Petróleo 20).

Bosetti, E.P. 1989a. Proposição de uma sistemática artificial para lingulídeos fósseis, baseada no estudo de lingulídeos da Formação Ponta Grossa (Devoniano), Bacia do Paraná, Brasil. In: CONGRESSO BRASILEIRO DE PALEONTOLOGIA, 11, 1989. Anais, Curitiba, p. 53-71.

Bosetti, E.P. 1989b. Revisão sistemática dos Lingulida (Brachiopoda: Inarticulata) da Formação Ponta Grossa (Devoniano), Bacia do Paraná, Brasil. In: CONGRESSO BRASILEIRO DE PALEONTOLOGIA, 11, 1989. Anais, Curitiba, p. 72-89.

Bosetti, E.P. 2004. Tafonomia de alta resolução das fácies de offshore da sucessão devoniana na região de Ponta Grossa, Paraná, Brasil. Programa de Pós-Graduação em Geociências, Universidade Federal do Rio Grande do Sul, Ph.D. thesis, 165 p.

Bosetti, E.P.; Grahn, Y.; Horodyski, R.S.; Mauller, P.M.; Breuer, P. \& Zabini C. 2010. An earliest Givetian "Lilliput effect" in the Paraná Basin, and the collapse of the Malvinokaffric shelly fauna. Palaeontologische Zeitschrift, 85:49-65.

Bosetti, E.P. \& Moro, N.S. 1989. Análise da estrutura e diversidade morfotípica de lingulídeos em algumas paleocomunidades fossilizadas in situ na Formação Ponta Grossa (Devoniano), Bacia do Paraná, Brasil. In: CONGRESSO BRASILEIRO DE PALEONTOLOGIA, 11, 1989. Anais, Curitiba, p. 92-104. 
Branisa, L. 1965. Los fósiles guías de Bolivia: index fossils of Bolivia. Serviço Geológico de Bolivia, 6:282.

Branisa, L. \& Vanek, J. 1973. Several new trilobite genera of the superfamily Dalmanitaceae Vodges, 1890 in the Devonian of Bolivia. Vestnik Ustredni Ustav Geologicky, 48:97-102.

Carvalho, M. da G.P. \& Edgecombe, G.D. 1991. Lower- early middle Devonian calmoniid trilobites from Mato Grosso, Brazil, and related species from Paraná. American Museum Novitates, 3022:1-13.

Carvalho, M. da G.P. \& Edgecombe, G.D. 2006. Paranacaste pontagrossensis Popp, 1989 (Trilobita: Acastoidea): Proposed Conservation of the Taxon. Journal Information, 80:581-582. doi:10.1666/0022-3360(2006)80[581:PPPTAP]2.0.CO;2

Carvalho, M. da G.P.; Edgecombe, G.D. \& Lieberman, B. S. 1997. Devonian Calmoniid trilobites from the Parana Basin, Piauí State, Brazil. American Museum Novitates, 3192:1-11.

Ciguel, J.H.G. 1989. Bioestratigrafia dos Tentaculoidea no flanco oriental da Bacia do Paraná e sua ocorrência na América do Sul (Ordoviciano - Devoniano). Instituto de Geociências, Universidade de São Paulo, M.Sc. thesis, 237 p.

Cerri, C.A.D. 2013. Revisão sistemática dos Brachiopoda (Calciata), da Formação ponta Grossa, Devoniano (LochkovianoEmsiano), Bacia do Paraná, Brasil: Implicações tafonômicas e estratigráficas. Programa de Pós-Graduação em Geoquímica e Geotectônica, Universidade de São Paulo, M.Sc. thesis, 104 p. doi:10.11606/D.44.2013.tde-30032015-151753

Clarke, J.M. 1890. As Trilobitas do Grez de Ereré e Maecurú, Estado do Pará, Brasil. Archivos do Museu Nacional do Rio de Janeiro, 9:1-58.

Clarke, J.M. 1913. Fósseis devonianos do Paraná. Rio de Janeiro, Serviço Geológico e Mineralógico do Brasil, 353 p. (Monografias 1).

Cooper, M.R. 1982. A Revision of the Devonian (Emsian - Eifelian) trilobita from the Bokkeveld Group of South Africa. Annals of the South African Museum, 89:1-174.

Copper, P. 1977. Paleolatitudes in the Devonian of Brazil and the Frasnian - Famennian mass extinction. Palaeogeography, Palaeoclimatology, Palaeoecology, 21:165-207.doi:10.1016/00310182(77)90020-7

Della Valle, A. 1893. Gammarini del Golfo di Napoli. Berlim, Zoologischen Station Zu Neapel, 948 p. (Fauna und Flora des Golfes von Neapel und der angrenzenden Meeres-Abschnitte, Monographie 20).

Delo, D.M. 1935. A revision of the Phacopid trilobites. Journal of Paleontology, 9:402-420.

Delo, D.M. 1940. Phacopid trilobites of North America. Geological Society of America, 29:1-134. doi:10.1130/SPE29-p1

Edgecombe, G.D.1994. Calmoniid trilobites from the Devonian Fox Bay Formation, Falkland Islands. In: E. Landing (ed.) Studies in Stratigraphy and Paleontology in Honor of Donald W. Fisher, New York, The University of the State of New York, p. 55-68 (New York State Museum Bulletin 481).

Eldredge, N. \& Branisa, L. 1980. Calmoniid trilobites of the Lower Devonian Scaphiocoelia Zone of Bolivia, with remarks on related species. Bulletin of the American Museum of Natural History, 165:181-289.

Eldredge, N. \& Ormiston, A.R. 1979. Biogeography of Silurian and Devonian Trilobites of the Malvinokaffric Realm. In: A.J. Boucot \& J. Gray (eds.) Historical Biogeography, Plate Tectonics, and Changing Environment, Oregon State University Press, p. 147-167.

Ghilardi, R.P. 2004. Tafonomia comparada e paleoecologia dos macroinvertebrados (ênfase em Trilobites), da Formação Ponta Grossa (Devoniano, Sub-bacia Apucarana), Estado do Paraná,
Brasil. Programa de Pós-Graduação em Geologia Sedimentar, Universidade de São Paulo, Ph.D. thesis, 113 p.

Ghilardi, R.P. \& Simões, M.G. 2007. History and Development of Trilobite Research in Brazil. In: D.G. Mikulic; E. Landing \& J. Kluessendorf(eds.) Fabulous Fossils - 300 years of worldwide research on trilobites, New York, The University of the State of New York, p. 97-104 (New York State Museum Bulletin 507).

Holz, M. \& Schultz, C.L. 1998. Taphonomy of the south Brazilian Triassic herpetofauna: fossilization mode and implications for morphological studies. Lethaia, 31:335-345. doi:10.1111/j.1502-3931.1998.tb00523.x

Kotzian, C.B. 1995. Estudo sistemático e morfo-funcional de bivalves (Mollusca) das Formações Vila Maria (Siluriano) e Ponta Grossa (Devoniano), Bacia do Paraná, Brasil: interpretação do regime hidrodinâmico-sedimentar. Instituto de Geociências, Universidade Federal do Rio Grande do Sul, Ph.D. thesis, $378 \mathrm{p}$.

Kotzian, C.B. 2003. A new Devonian Modiolopsidae (Mollusca: Bivalvia) from the Ponta Grossa Formation, Paraná Basin, Brazil. Pesquisas em Geociências, 30:27-32.

Kotzian, C.B. \& Marchioro, A. 1997. Gastrópodes (Mollusca) devoniados da Formação Ponta Grossa (bacia do Paraná). Gêneros: Ptomatis Clarke, 1899, Pleurotomaria (?) Defrance, 1826 e Platyceras Conrad, 1840. Ciência e Natura, 19:143-185.

Kozlowski, R. 1913. Fossiles Devoniens de l'État de Paraná (Brésil). Annales de Paleontologie, 8:14-19.

Kozlowski, R. 1923. Faune dévonienne de Bolivie. Annales de Paleontologie, 12:1-112.

Lange, F.W. 1954. Paleontologia do Paraná. In: F.W. Lange (ed.) Paleontologia do Paraná, Comissão de Comemoração do Centenário do Paraná, p. 1-105.

Lange, F.W. \& Petri, S.1967. The Devonian of the Paraná Basin. In: J.J. Bigarella (ed.) Problems in Brazilian Devonian Geology, Curitiba, Universidade Federal do Paraná, p. 5-55 (Boletim Paranaense de Geociências 21)

Leme, J.M. 2002. Revisão sistemática dos Conulatae Collins et al., 2000, Formação Ponta Grossa, Devoniano (?Lochkoviano - Frasniano), Bacia do Paraná, Brasil: implicações paleobiogeográficas e comentários sobre as relações filogenéticas entre os Conulatae. Programa de Pós-graduação em Geologia Sedimentar, Universidade de São Paulo, M.Sc. thesis, 112 p. doi:10.11606/D.44.2002.tde-17092013-095045

Leme, J.M.; Mori, A.S. \& Batista, L.A. 2010. Systematic revision of the Calmoniidae (Phacopida, Trilobita) from the Devonian Ponta Grossa Formation, Paraná Basin, Brazil. In: CONGRESSO ARGENTINO DE PALEONTOLOGIA E BIOESTRATIGRAFIA E CONGRESSO LATINOAMERICANO DE PALEONTOLOGIA, 10, 7, 2010. Boletim de Resumos, La Plata, p. 177-178.

Leme, J.M.; Rodrigues, S.; Simões, M. \& Iten, H.V. 2004. Sistemática dos conulários (Cnidaria) da Formação Ponta Grossa (Devoniano), do Estado do Paraná, Bacia do Paraná, Brasil. Revista Brasileira de Paleontologia, 7:213-222.

Leme, J.M.; Simões, M.; Marques, A. \& Iten, H.V. 2008. Cladistic analysis of the suborder Conularinna Miller and Gurley, 1896 (Cnidaria, Scyphozoa, Vendian/Triassic). Palaeontology, 51:649-662. doi:10.1111/j.1475-4983.2008.00775.x

Lieberman, B.S. 1993. Systematics and biogeography of the "Metacryphaeus Group" Calmoniidae (Trilobita, Devonian), with comments on adaptative radiations and the geological history of the Malvinokaffric Realm. Journal of Paleontology, 67:549-570. doi:10.1017/S0022336000024902 
Lieberman, B.S.; Edgecombe, G.D. \& Eldredge, N. 1991 Systematics and biogeography of the "Malvinella Group", Calmoniidae (Trilobita, Devonian). Journal of Paleontology, 65:824-843. doi:10.1017/S002233600003780X

Lucas, S. 2001. Taphotaxon. Lethaia, 34:30. doi:10.1080/ 002411601300068198

Marchioro, A.; Kotzian, C.B. \& Simões, R.I. 1998. Belerofontinas (Mollusca: Gastropoda?) devonianos do Estado do Paraná (Formação Ponta Grossa, Bacia do Paraná): Gênero Bucanella Meek, 1871. Ciência e Natura, 20:143-185.

Melo, J.H.G. 1988. The Malvinokaffric realm in the Devonian of Brazil. In: N. J. McMillan, A. F. Embry, \& D. J. Glass (eds.) Devonian of the World, Volume I, Canadian Society of Petroleum Geologists, p. 669-703.

Méndez-Alzola, R. 1938. Fósiles devónicos del Uruguay. Boletin Instituto de Geologia y Perforaciones, 24:3-115.

Mori, A.S. 2013 Revisão sistemática dos Calmoniidae (Trilobita, Phacopida) da Formação Ponta Grossa, Devoniano, Bacia do Paraná, Brasil. Programa de Pós-Graduação em Geoquímica e Geotectônica, Universidade de São Paulo, M.Sc. thesis, 67 p.

Mori, A.S \& Leme, J.M. 2012. Revisão sistemática de Calmoniidae (Trilobita, Phacopida) da Formação Ponta Grossa (Devoniano), Bacia do Paraná, Brail. In: SIMPÓSIO BRASILEIRO DE PALEONTOLOGIA DE INVERTEBRADOS, 1, 2012. Boletim de Resumos, Bauru, p. 77.

Morley, C. 1903. Ichneumonologia brittannica - The ichneumons of Great Britain; a descriptive account of the families, genera and species indigenous to the British islands, together with notes as to classification, localities, habitats, host, etc. Plymouth, J.H. Keys, 315 p.

Petri, S. 1948. Contribuição ao estudo do Devoniano paranaense. Boletim do Departamento Nacional de Produção Mineral, 129:1-125.

Popp, M.T.B. 1985. Revisão dos trilobitas calmoniídeos e comunidades faunísticas da Formação Ponta Grossa, Devoniano do Estado do Paraná. Instituto Geociências, Universidade Federal do Rio Grande do Sul, Ph.D. thesis, 112 p.

Popp, M.T.B. 1989. Paranacaste um novo gênero de trilobita da Formação Ponta Grossa, Bacia do Paraná. In: CONGRESSO BRASILEIRO DE PALEONTOLOGIA, 11, 1989. Anais, Curitiba, p. 19-35.

Popp, M.T.B.; Coimbra, J.C. \& Hauch, A. 1996. Revisão do gênero Paracalmonia Struve, 1958 (Proboloides Clarke, 1913), Trilobita - um ensaio de sistemática filogenética. Gaia, 12:19-32.

Quadros, R. 1987. Paleontologia dos rachiopoda - Lingulida, Strophomenida, Spiriferina, Terebratulida - devonianos, da Serra de Atimã e arredores, Mato Grosso, Brasil. Instituto de Geociências, Universidade Federal do Rio Grande do Sul, Ph.D. thesis, $87 \mathrm{p}$.

Reed, F.R.C. 1907. The fauna of Bokkeveld beds. Geological magazine, 4:164-232. doi:10.1017/S0016756800131711

Reed, F.R.C. 1925. Revision of the fauna of the Bokkeveld beds. Annals of the South African Museum, 22:122-163.

Reed, F.R.C. 1927. Recent work on the Phacopidae. Geological Magazine, 64:308-322, 337-353. doi:10.1017/S0016756800103590

Rennie, J.V.L. 1930. Some Phacopidae from the Bokkeveld Series. Transactions of the Royal Society of South Africa, 18:327-360. doi:10.1080/00359193009518815

Richter, R. \& Richter, E. 1942. Die Trilobiten der Weismes-Schichten am Hohen Venn, mit Bemerkungen uber die Malvinocaffrische Provinz. Senckenbergiana, 25:156-179.
Rodrigues, S.C.; Leme, J.M. \& Simões, M.G. 2003. Tafonomia Comparada dos Conulatae (Cnidaria), Formação Ponta Grossa (Devoniano), Bacia do Paraná, Estado do Paraná. Revista Brasileira de Geociências, 4:1-10.

Salter, J.W. 1856. On fossil remains in the Cambrian rocks of the Longmynd and North Wales. Quarterly Journal of the Geological Society, 12:246-251. doi:10.1144/GSL.JGS.1856.012.01-02.31

Simões, MG.; Leme, J.M. \& Soares, S.P. 2009. Systematics, taphonomy, and paleoecology of homalonotid trilobites (Phacopida) from the Ponta Grossa Formation. Revista Brasileira de Paleontologia, 12:27-42. doi:10.4072/rbp.2009.1.03

Simões, M.G.; Rodrigues, S.; Leme, J.M. \& Iten, H.V. 2003. Some Middle Paleozoic Conulariids (Cnidaria) as Possible Examples of Taphonomic Artifats. Journal of Taphonomy, 1:165-186.

Soares, S.P. 2007. Sistemática, Tafonomia e Paleoecologia de Trilobita, Phacopida (Homalonotidae, Calmoniidae), Formação Ponta Grossa (Devoniano), Sub-bacia Apucarana, Estado do Paraná, Brasil. Instituto de Geociências, Universidade de São Paulo, M.Sc. thesis, 140 p. doi:10.11606/D.44.2007.tde15052008-113100

Soares, S.P.; Simões, M.G. \& Leme, J.M. 2008a. Metacryphaeus rotundatus, um Novo Elemento da Fauna de Trilobites Calmoniidae (Phacopida), da Formação Ponta Grossa (Devoniano), Bacia do Paraná, Brasil. Geologia USP, Série Cientifica, 8:15-24. doi:10.5327/Z1519-874X2008000100002

Soares, S.P.; Simões, M. \& Leme, J.M. 2008b. O papel da fossilização e do intemperismo na sistemática dos trilobites Phacopida (Calmoniidae e Homalonotidae), Formação Ponta Grossa, (Devoniano), Bacia do Paraná, Brasil. Revista Brasileira de Paleontologia, 11:59-68.

Struve, W. 1958.Uber einige Fälle von Homonymie bei Gattungen der Phacopacea. Senckenbergiana Lethae, 39:301-302.

Struve, W. 1959. Trilobita. In: R.C. Moore (ed.) Treatise on Invertebrate Paleontology Part O. Arthropoda, Geological Society of America and University of Kansas Press, p. 483-489.

Thomas, A.T. 1977. Classification and phylogeny of homalonotid trilobites. Palaeontology, 20:159-178.

Ulrich, A. 1892. Paleozoiche Versteinerungen aus Bolivien. In: G. Steinman (ed.) Beitrage zur Geologie und Paleontologie von Sudamerika, Schweizerbart, p. 1-116.

Wolfart, R. 1968. Die Trilobiten aus dem Devon Boliviens und ihre Bedeutung für Stratigrtaphie und Tiergeographie. Beiträge zur Kenntnis des Devons von Bolivien, 74:5-201.

Zabini, C. 2007. Lingulídeos da sucessão devoniana da Bacia do Paraná, região dos Campos Gerais, Brasil: revisão de conceitos biológicos-ecológicos e análise tafonômica básica. Programa de Pós-Graduação em Geociências, Universidade Federal do Rio Grande do Sul, M.Sc. thesis, 120 p.

Zabini, C. 2011. Integração da tafonomia e estratigrafia de sequências no estudo dos lingulídeos da sucessão Devoniana da Bacia do Paraná. Programa de Pós-Graduação em Geociências, Universidade Federal do Rio Grande do Sul, Ph.D. thesis, 238 p.

Zabini, C.; Schiffbauer, J.D.; Xiao, S. \& Kowaleski, M. 2012. Biomineralization, taphonomy, and diagenesis of Paleozoic lingulide brachiopod shells preserved in silicified mudstone concretions. Palaeogeography, Palaeoclimatology, Palaeoecology, 326-328:118-127. doi:10.1016/j.palaeo.2012.02.010

Received in March, 2016; accepted in June, 2016. 